\title{
The Main Reasons for Implementing BPM in Czech Companies
}

\section{- Tuček David}

\begin{abstract}
This article focuses on describing the main aspects and reasons for implementing Business Process Management in Czech companies, and was based on original results of the quantitative research evaluating aspects of process management in the context of company strategies in Czech enterprises which was carried out in 2006 with regard to the extension of its further utilization. Following the interest of professionals in practice, the research continued and was re-implemented in 2012, having the interviews completed in 2013.

I have described an evaluation of a process segmentation typology in this article too. The analysis showed that managers have more options regarding process segmentation to choose from. In terms of practicality and ease of use, the method of process segmentation most frequently used (managerial, main and supportive) comes directly from the requirements of ISO 9001.
\end{abstract}

Keywords: Business Process Management, quantitative research, implementation, process segmentation typology JEL Classification: M11, M15, M100

\section{INTRODUCTION}

Business process management, or simply process management, can be defined as a methodology for evaluation, analysis and improvement of key business processes based on customers' needs and desires. However, BPM is a step forward in terms of dynamics typical for today's business world. The process is based not only on "what" but also on "how" (Basl \& Sasiadek, 2014). In many discussions, a question arises whether management is an art or a science. Concerning this topic, it is possible for BPM to state that it is the art and science about how we do things and how we can do things even better (Lehmann, 2012).

To understand better the aspects of a process approach, Závadský emphasizes the following factors (Šatanová et al., 2014):

- focus on objectives and outputs of the process regardless the boundaries in the form of crossing of various departments created according to the functions of the company;

- define internal market suppliers and customers (in many companies based on service - oriented architecture, the basis is having internal service contracts between process owners);

- identify critical areas of value conception for customers faster than in the case of hierarchical functional structures;

- optimize the cost structure to the calculation unit;

- achieve business processes innovations faster by having sequence of activities and their attributes; 
- identify the relationship between the strategic goals of the enterprise, business processes and performance of sources connected with the activities stated.

The strategy is directly connected with the other definitions, this time defined by the authors Jeston and Nelis (2008) who characterize process management as the achievement of strategic goals of organization through improvement, management and control of key business processes.

Adding interfaces between processes an organization can conceptualize its value chain (Harmon, 2014) and thus processes become subsystems of wider systems. In their paper, Segatto, Pádua \& Martinelli (2013) identified several characteristics of BPM as a systemic discipline:

- Enterprise is viewed as an open system with inputs, processing and output.

- It ensures alignment with strategic goals.

- Feedback is valued for improving the processes.

- It focuses on integrating the activities and their inter-relationships.

- It goes beyond the functional silos, enabling a full image of the organization and processes to be constructed.

\section{THEORETICAL BACKGROUND}

I should begin with the principles. Managers are often confronted, even in renowned magazines, with several similar terms and concepts which may be confusing or at least their correct content and principles may be misinterpreted on the basis of inaccurate information. What do the terms Business Process Management (BPM) and Business Process Reengineering (BPR) mean? What is their application in practice? In this subchapter, I would like to acquaint you briefly but precisely with these terms and their content.

From the point-of-view of management and Business Process Management development, authors such as King, Fingar, Smith etc. have offered various conceptions in order to comprehend the connections and differences between them. King, for instance, has distinguished between four development waves BPM (Smith \& Fingar, 2007).

He has mentioned the following in his publications:

- The first wave of BPM - concentrated on constant improving of the processes and coincides in many ways with the philosophy of TQM (Total Quality Management), a philosophy which leads to an increase in productivity, a simultaneous increase in quality and increased customer satisfaction while decreasing losses caused by poor quality production. TQM is thus a systematic and consistent application of several methods within the company organization clearly concentrating on quality and customer satisfaction.

- The second wave of BPM - consisted of a focus on Business Process Reengineering, or in short Reengineering. This is regarded as the second wave involving the trend in management leading towards essential, radical and fundamental changes in the organization of applied work procedures or technologies. The achievement of not merely incremental but has a radical rise in organization productivity as the expected result. 
- The third wave of BPM - the authors Fingar and Smith (2007) refer to activities leading to the creation of a process-focused organization. This involves the application of main component procedures or process management consisting of the following:

- key process determination including the appointment of process possessors and customers;

- within the process description, their mapping and a process map formation (a company process model) for recording process system management;

- the application of process maps (models) for the purpose of cost intensity evaluation and increases in their efficiency;

- ongoing process improvement and measuring the efficiency;

- quality in the enterprise is mainly understood as the demand for quality standards which lead off the process model;

- information technologies considered as the process support in the enterprise;

" while the process model represents the basis of the process management, the strategy management is comprehended as the peak of the "pyramid" of process management;

- competence management is understood as a system to fulfil the roles in individual processes (both management and key processes) by those people who have appropriate knowledge and abilities for them (Cambal et al., 2013).

Therefore, many IS/ICT applications are connected with the BPM. Some authors, e.g. (Gelogo, 2014) define the Enterprise Resource Planning (ERP) as business process management software that allows an organization to use a system of integrated applications to manage the business and reset office functions.

\subsection{Definition of the Process}

The definitions of processes are focused on certain different items. Etjnen G. Rummler and A. Brache (1995) define a business process with the focus on external customers of an organisation: "a business process is a series of steps designed to produce a product or service".

Business process managers use processes as means of achieving organization's objectives through their management, improvement and governance (Jeston \& Nelis, 2014). The authors agree that a business process is any set of interrelated activities that create results valuable to their customers (Hammer, 2003) or simply the way how things are done (Lehmann, 2012; Jeston \& Nelis, 2014).

Every process has an output valuable for a customer. Customers can be external or internal thus processes can be distinguished as core or key, supportive and management processes. (Lehmann, 2012) I can divide the process into activities. The activities as parts of a process with connections and loops among each other, including applications, roles, documentation, etc., characterize the process's behaviour.

Most processes are cross-functional, spanning the 'white-space' between the boxes on the organization chart. Some processes result in a product or service that is received by an organization's external customer. I call these primary processes. Other processes produce products that 
are invisible to the external customer but essential to the effective management of the business. We call these support processes. This definition distinguishes between two types of processes: primary and support processes, depending on whether a business process

is internal or external. If it is internal, it is a support process. If it is external for a customer, it is the primary process then. (Stankevičius \& Vasilecas, 2014)

T. Debevoise (2007) and M. Dumas et al. (2005) stated that business processes and other components of BPM like business modelling, business process simulation and implementation measures are considered to be one of the most effective ways to increase the efficiency of business processes and productivity. This is of the utmost importance to many modern organisations.

Terms "modelling" and "simulation" are often used synonymously. However, Stankevičius and Vasilecas (2014) regard modelling as an act of building a model whereas simulation is an act or even a process of using that model for a specific purpose or study. Business process simulation can be used for different purposes of course.

\subsection{A Process Owner or a Process Steward?}

Process ownership is one of the main pillars of BPM. Early reengineering proponents Hammer and Champy (2003) and Hammer and Stanton (1995) stressed the importance of process owners. Process owners should be senior-level managers responsible for reengineering of a process, its performance measurement and further improvement. As processes are often cross-functional, a process owner's responsibility should be also cross-functional (Robson \& Ullah, 1996). In traditional organization, these are to be represented by its structure. Individual functional departments with its managers - leaders, execute particular parts of a process. The task of a process owner is therefore to optimize the process as a whole through negotiation with functional managers, performance measurement and improvement projects. A matrix-like organization structure may develop as process models gradually overlap and complement the organizational structure. As Nesheim (2011) states, process owners cooperate with functional managers and define the key performance indicators consistently with strategic goals. Nesheim (Ibid.) further identifies these tasks of process owners:

- standardization of work processes regarding documentation based on best practices. Handling improvement proposals and monitoring activities;

- competence development by establishing requirements and facilitating strategic expertise development;

- personnel deployment and allocation of resources.

Several terms exist for a process owner such as a process steward (Panagacos, 2012) or a process manager (Harmon, 2014). However, the nature of the role remains the same.

\subsection{BPM Implementation}

It is possible apply to the BPM in certain different ways. One of them is connected with the fractal geometry. Van Rensburg's (2014) research hypothesis proved that business problems contain organised patterns that are part of larger business systems. By applying this logical aspect 
in the modelling and design of business processes, I can state that business processes contain organised patterns of business activities. Using this approach, fractals can be used to understand the complexity of a business system, and hence its associated business processes and appropriate designs.

Generally speaking, the implementation in different services and production processes can be similar. All too often, we use specific SW for design, simulation and optimisation. According to the BPM model, which has been designed by a process modeller, the process developer should generate common data to be used in all tasks of the process and unit data to be used in the specific task only. In addition, the process developer would make the external functions or programmes using native programming language such as Java or $\mathrm{C}$, and interface these to the specific task in the BPM model. If the task is of a human type, then according to the UI design by the process modeller, the process developer should develop the form pages through a detailed data setting. If the task is of a script or service type, then the process developer must implement internal functions or programmes using the script language which is supported in the BPMS (Son \& Kim, 2014).

BPM implementation we can describe like a process with the following six tasks: discovery (clarification of how business processes work), design (building product definition models (PDMs) for business processes), execution (providing enactment services), operation (interacting with participants while monitoring the business processes), optimization (improving PDM), and analysis. (Smith \& Fingar, 2007)

But some authors (Aalst et. al, 2000) define BPM more widely: "after the adaptation of the workflow as an approach to grasp and execute works from the perspective of a process, BPM was introduced with the intent of achieving the continuous monitoring and improvement of a process through the closed loop of "plan-do-check-act," including the complete roles of a workflow".

\section{OBJECTIVES AND METHODOLOGY}

The research aim of the article was to analyse the main aspects and reasons for implementing Business Process Management in Czech companies and evaluation of process segmentation typology too.

We did a wide-ranging research aimed at the utilization level of business process management in 144 especially Czech manufacturing companies in 2006 and in 2012/2013.

The research specialized in the area of goals, factors, components, support, benefits and barriers of process management. The utilization level of BPM in Czech companies was determined by self-assessment of managers and according to the actual utilization of BPM components.

The whole research has also clarified goals and procedures that are important for Czech companies regarding the use of BPM components, and stated the extent to which the addressed companies use a software support of process management. Moreover, the research also focused on identifying the benefits that the company achieved by BPM implementation and on identifying barriers which Czech companies faced when implementing BPM. The results of this research are too spread. Therefore, I focused in this article only on analysis of the main aspects and reasons 
for implementing Business Process Management in Czech companies and evaluation of process segmentation typology.

The whole research had eight main goals but in this article, I only introduce two of them:

Research goal no. 2. Clarify the main aspects and reasons that are important for Czech companies when implementing the process management components.

Research goal no. 4. Evaluate which process segmentation is preferred by the company, i.e. segmentation according to ISO 900X, BSC, Porter or others, and highlight the process areas in which the rated companies bide their imperfections.

A part of this article presents comparison of the results of our previous research done in 2006 (Tuček, Tučková \& Zamečník, 2009) and the current research. The comparison of these findings allows identifying some interesting trends in business process management in Czech companies for the past 6 years. A sample of 300 randomly chosen firms was used. The return of questionnaires was 144 , which is $48 \%$.

Tab. 1 - Distribution of respondents by number of employees. Source: own analysis.

\begin{tabular}{|l|c|c|c|}
\hline \multicolumn{2}{|c|}{ Characteristics of a company } & \multicolumn{2}{c|}{ Number of evaluated companies } \\
\hline $\begin{array}{c}\text { Number } \\
\text { of employees }\end{array}$ & Absolute frequency & Relative frequency \\
\hline Micro companies & $1-19$ & 36 & $25 \%$ \\
\hline Small companies & $20-49$ & 20 & $13.89 \%$ \\
\hline $\begin{array}{l}\text { Medium-sized com- } \\
\text { panies }\end{array}$ & $50-250$ & 43 & $29.86 \%$ \\
\hline Large companies & 250 and more & 45 & $31.25 \%$ \\
\hline TOTAL & 144 & $100 \%$ \\
\hline
\end{tabular}

The structure of respondents is to be seen in Tab. 1. To minimize the risk of acquiring an insufficient number of completed questionnaires, the authors addressed key employees of selected companies by phone first, and then the questionnaire was sent. When processing questionnaire results, all 144 companies were included.

The aim of this research was to explore attitudes, opinions and judgments of managers of Czech companies regarding individual aspects of business process management.

Based on the character of quantifying qualitative data, a scaling method was used in this research. The reason for this is that managers' responses include subjective statements which must be subsequently converted using a verbally, numerically or graphically expressed scale. In fact, I used Likert scale method. Likert scales are used to indicate the degree (level) of agreement or disagreement with the specified statements, from which it is subsequently possible to deduce the attitudes and opinions of respondents (Croasmun \& Ostrom, 2011).

For the purpose of describing the research results from 2013, I used the descriptive statistics methods such as description and others. Relative representation in the responses was detected and the basic characteristics of location and variability were identified. Median was chosen as 
an ordinal mean value and discrete ordinal variance (dorvar) was used as the characteristic of variability. Calculation of both variables was implemented according to VŠE C 2014. In order to organize and arrange the findings obtained using a questionnaire survey and to prepare data for statistical evaluation, Excel software was used. The actual statistical evaluation was carried out using JMP 10 (in 2006) and application R, SPSS Statistics and Microsoft Excel.

At ordinal variable, median category $(\mathrm{Me})$ belongs to measures of position. It is the category for which the cumulative frequency $(\mathrm{P})$ is 0,5 or higher whereas for the previous category, the cumulative frequency was less than 0,5. This means that PMe-1 $<0,5$ and $\mathrm{PMe} \geq 0,5$. (Tuček, Mikeska, 2015).

Furthermore, the median can be calculated, more specifically, according to the formula:

The median $=M_{e}-0,5+\frac{0,5-P_{M e-1}}{P_{M e}}$

For variability rate of the basic set, we may use so-called dorvar ordinal scattering (discrete ordinal variance) (VŠE C 2014) determined by the formula:

dorvar $=2 \sum_{i=1}^{K} P_{i}\left(1-P_{i}\right)$

This rate expresses the exact difference of all pairs. While rewriting the interval from 0 to $1, \mathrm{I}$ will get normalized norm. dorvar ordinal scattering for which the following formula is applied:

norm. dorvar $=2 \times$ dorvar $/(K-1)$, norm. dorvar $\hat{I}<0 ; 1>$

Null and alternative hypotheses were developed and tested by different non-parametrical means. When investigating dependency of nominal and ordinal data, Pearson's Chi Square test was used at the selected significance level of $\alpha=0,05$ where dependency between the selected ordinal variables was proven at the selected significance level of $\alpha=0,05$, a null hypothesis about independency was rejected in favour of an alternative hypothesis supporting assumption of relationship between variables.

\section{RESULTS AND DISCUSSION}

\subsection{The Main Reasons for Implementing BPM in the Czech Republic}

The Evaluation of specific questions in my questionnaire contributes to a better clarification of opinion on how process management is perceived by managers. Simultaneously, it illustrates the previous questions about what aims managers monitor by using process management. In general, process management is perceived as a strategic change which affects the processes. In 2006, managers specified the most significant reasons for this change:

- high inefficiency of the process identified (at the level of 0,64);

- reorganization of the company requiring a different flow of the process (at the level of $0,60)$. 
After implementing the changes (processes) through process management, the managers considered these reasons as being moderately significant:

- lack of competitiveness of the company;

- change in IT support process;

- the need to provide a new product or service.

Fig.1 also shows that the acquisition factor or merge in the enterprise (declared during the growth of the company or during acquisition of new companies, i.e. by merging with other company) proved as little significant (at the level of 0,40 ). Other elements were reported by managers only marginally.

How has this understanding changed after about 6 years?

As it is evident from Tab. 2, three same reasons have been revealed in the top four list and the following ones are of the highest importance:

- identification of high inefficiency of the process;

- reorganization of the company requiring a different process development;

- lack of competitiveness.

According to the level of importance, a change in IT support process is the most significant one. It has the highest value of median factor and the lowest for dispersion: The median $=3,854$. As seen, dispersion is still relatively high (dorvar $=1,204)$ and modus $=4$ refers to a high level of importance of IT change for managers.

Tab. 2 - The concept of process management (in 2013) -descriptive statistics and its graphical representation. Source: own analysis.

\begin{tabular}{|c|c|c|c|c|c|c|}
\hline $\begin{array}{l}\text { Answers } \\
\text { option }\end{array}$ & $\begin{array}{l}\text { X6.1 } \\
\text { Inefficient } \\
\text { business } \\
\text { processes }\end{array}$ & $\begin{array}{l}\text { X6.2 } \\
\text { Reorgani- } \\
\text { zation of } \\
\text { the com- } \\
\text { pany }\end{array}$ & $\begin{array}{l}\text { X6.3 } \\
\text { Insuf- } \\
\text { ficient } \\
\text { competi- } \\
\text { tiveness }\end{array}$ & $\begin{array}{l}\text { X6.4 } \\
\text { Change in } \\
\text { IT support } \\
\text { process }\end{array}$ & $\begin{array}{l}\text { X6.5 } \\
\text { Provid- } \\
\text { ing a new } \\
\text { product or } \\
\text { service }\end{array}$ & $\begin{array}{l}\text { X6.6 } \\
\text { Acquisition } \\
\text { or merge }\end{array}$ \\
\hline $\begin{array}{l}\text { Median } \\
\text { value }\end{array}$ & 3,500 & 3,500 & 3,521 & 3,853 & 2,947 & 2,500 \\
\hline OR & 1,290 & 1,380 & 1,411 & 1,271 & 1,204 & 1,396 \\
\hline NOR & 0,645 & 0,690 & 0,706 & 0,635 & 0,602 & 0,698 \\
\hline modus & 4 & 4 & 4 & 4 & 3 & 1 \\
\hline
\end{tabular}

Due to the median and modus values presented in Tab. 2 and due to the density of responses emerging from graphical representation that is a part of the table, it can be stated that the process with high inefficiency is of a slightly lower importance. Acquisition or merge in the company (declared during the growth of the company or during acquisition of new companies, i.e. by merging with other company) has emerged as irrelevant, similarly as in the year 2006 (see Fig. 1 and Tab 2.). 

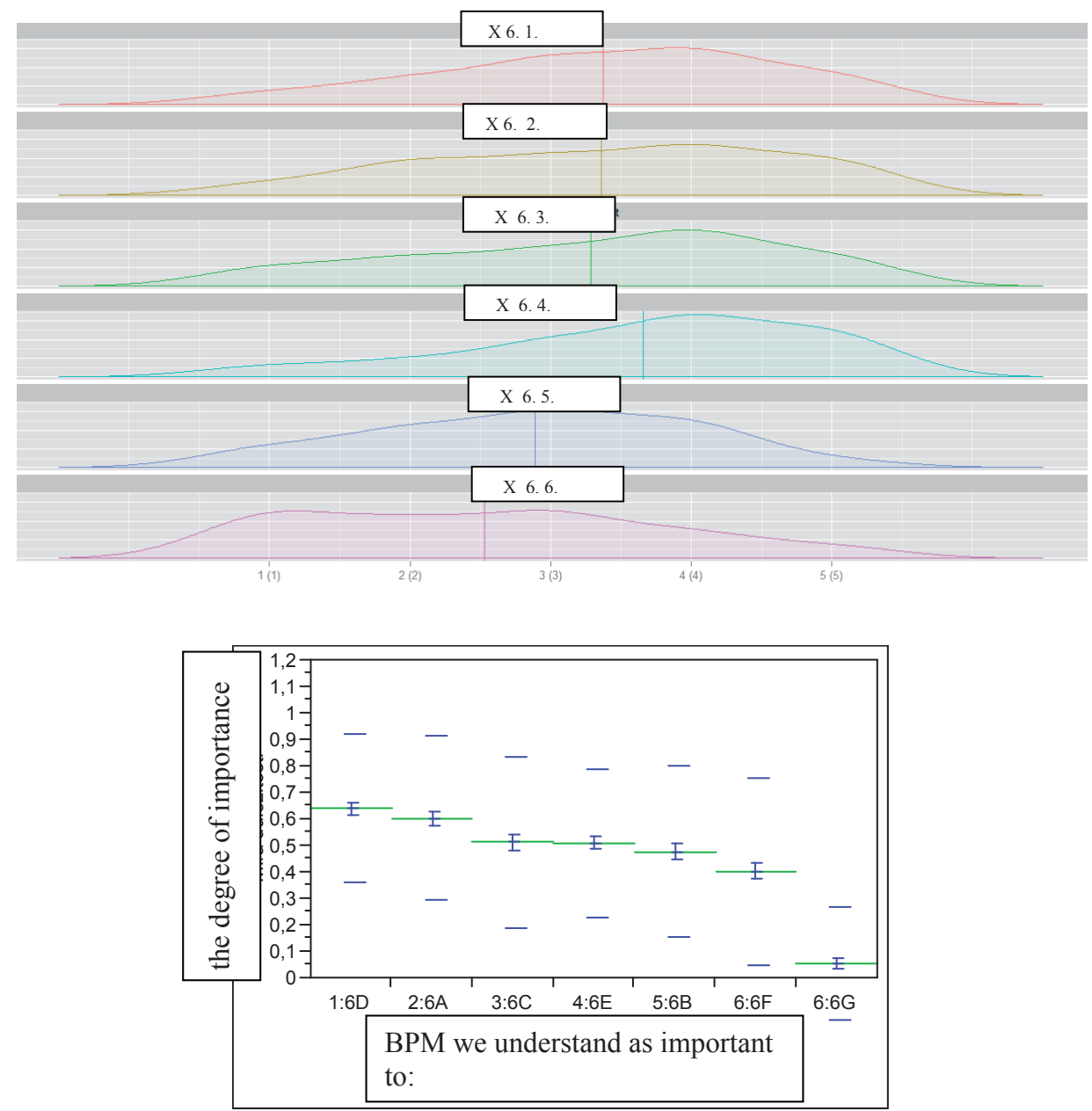

Fig. 1 - Process management approach (year 2006). Source: Tuček, Tučková and Zámě́ník 2009.

Tab. 3 - Process management approach - Reliability intervals (to estimate reliability $1-\alpha=$ 0,95). Source: Tuček and Zámečník 2007.

$\begin{aligned} & \text { Process management is perceived as } \\
& \text { important by managers due to these } \\
& \text { reasons:: }\end{aligned}$
\begin{tabular}{|l|l|l|l|l|} 
1:6D - inefficient business processes & 0,638258 & 0,280258 & 0,59000 & 0,68651 \\
\hline 2:6A - reorganization of the company & 0,602273 & 0,308831 & 0,54910 & 0,65545 \\
\hline 3:6C - lack of competitiveness & 0,511364 & 0,322300 & 0,45587 & 0,56686 \\
\hline 4:6E - change in IT support process & 0,507576 & 0,277907 & 0,45972 & 0,55543 \\
\hline
\end{tabular}




\begin{tabular}{|l|l|l|l|l|}
\hline 5:6B - providing a new product or service & 0,475379 & 0,325242 & 0,41938 & 0,53138 \\
\hline 6:6F - acquisition or merge & 0,401515 & 0,351873 & 0,34093 & 0,46210 \\
\hline 6:6G - other reasons & 0,054924 & 0,214713 & 0,01795 & 0,09189 \\
\hline
\end{tabular}

In case of reorganization of the company that required different process behaviour, the following factors have been demonstrated:

The size of the company and its effect can be interpreted by a statistical hypothesis. It is possible to confirm the alternative hypothesis H1, i.e.: "The size of the company according to the number of its employees (and turnover) is significantly associated with the fact that managers understand and evaluate the impacts of business processes due to reorganization of the company."

This is the evaluation regarding the second largest sector of process management, i.e. essential components. Its usage in the company feasibly meets the real process management principles. Process engineers sometimes call its summarization "Ten Commandments". Its application means a real usage of the process approach in practice.

The questionnaire also included so-called control questions which should confirm certain statements of the managers. Examples of these may be found in the second part of the questionnaire, i.e the seventh and eighth questions are related to the active usage of the components in process management mainly. These components should be used when managers answer the first question that their company fully or partially uses process management. In other words, the real usage of process management components in our companies is presented in the following paragraphs. Managers expressed their opinions regarding the topic also in other questions, and their opinions were often methodically correct. However, only answers to two questions are relevant for practical usage. These components were formulated as "Ten Commandments" and were included within the most important components that are essential for practical usage of process management in the company. Specifically, these are the components that were defined on the basis of qualitative and quantitative surveys in 2006 (Tuček, Tučková and Zámečník, 2009).

If we compare the development of the first survey in 2006, it is clear from Fig. 2 that the highest importance is attached to the following principles:

- management of authorities that is seen as a system enabling to assign; a role in individual processes (key and managerial) of such employees who have adequate knowledge and skills (at the level of 0,74 , see Tab. 4);

- information technology in the company that leads to support processes (at the level of $0,72)$.

In 2006, in the category of small businesses the lower importance was shown in the usage of information technologies for process support (at the level of 0,65 ) whereas when investigating large businesses in 2006, it was the principle with the largest weight. 


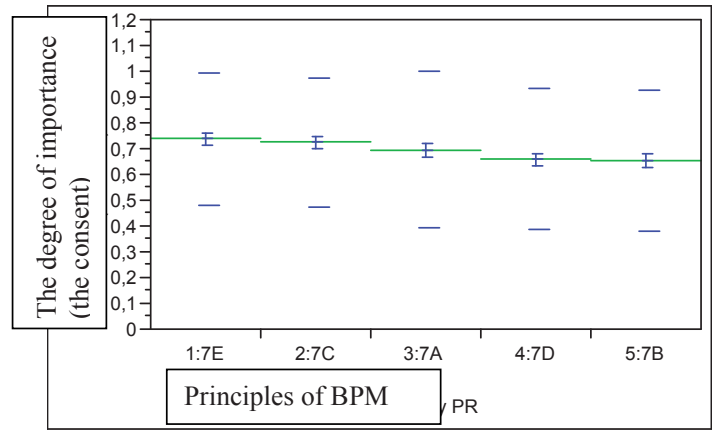

Fig. 2 - Significance of process management principles (in 2006). Source: Tuček, Tučková and Zámečník 2009.

Tab. 4 - Significance of process management principles - Reliability intervals (to estimate reliability $1-\alpha=0,95)$.

\begin{tabular}{|l|l|l|l|l|}
\hline $\begin{array}{l}\text { The importance of process management } \\
\text { principles from the managers' perspective }\end{array}$ & Average & $\begin{array}{l}\text { Standard } \\
\text { deviation }\end{array}$ & $\begin{array}{l}\text { Lower } \\
\text { int. }\end{array}$ & $\begin{array}{l}\text { Upper } \\
\text { int. }\end{array}$ \\
\hline $\begin{array}{l}\text { 1:7E - assigning a role in processes to appropri- } \\
\text { ate employees }\end{array}$ & 0,736742 & 0,257176 & 0,69246 & 0,78102 \\
\hline 2:7C - IT supporting processes & 0,723485 & 0,251442 & 0,68019 & 0,76678 \\
\hline $\begin{array}{l}3: 7 \mathrm{~A}-\text { quality is perceived as being required by } \\
\text { standards }\end{array}$ & 0,695076 & 0,304725 & 0,64261 & 0,74754 \\
\hline $\begin{array}{l}\text { 4:7D - strategic management is seen as the top } \\
\text { of process management pyramid }\end{array}$ & 0,659091 & 0,271539 & 0,61234 & 0,70585 \\
\hline $\begin{array}{l}5: 7 \mathrm{~B}-\text { standards are based on the process } \\
\text { model }\end{array}$ & 0,653409 & 0,272197 & 0,60654 & 0,70028 \\
\hline
\end{tabular}

\section{What about the situation in 2013 ?}

According to the values shown in Tab. 5, i.e. median $=4,052$, dispersion: dorvar $=0,993$ and modus $=4$, it is possible to conclude that the management of competences is understood as a system enabling the roles in different processes (key and managerial) by such employees who have the adequate knowledge and skills. Therefore, managers perceive management of competences as the most important principle; although the scattering of responses is relatively high.

The importance of information technologies in the company has shifted to the last imaginary place in terms of importance in 2013 compared to 2006.

However, the scattering response (dorvar) is relatively high in all of these results.

Controversial principles of understanding and quality management by respondents (including also quality managers) is rated as following: 
Tab. 5 - Meaning of process management principles - descriptive statistics including graphical representation. Source: own analysis.

\begin{tabular}{|l|l|l|l|l|l|}
\hline & $\begin{array}{l}\text { X7.1 } \\
\text { Quality is } \\
\text { considered } \\
\text { Answers } \\
\text { option }\end{array}$ & $\begin{array}{l}\text { X7.2 } \\
\text { Standards } \\
\text { required by } \\
\text { standards } \\
\text { from the } \\
\text { process } \\
\text { model }\end{array}$ & $\begin{array}{l}\text { X7.3 } \\
\text { IT supported } \\
\text { processes }\end{array}$ & $\begin{array}{l}\text { X7.4 } \\
\text { Strategical } \\
\text { management } \\
\text { is seen as the } \\
\text { peak of a proc- } \\
\text { ess manage- } \\
\text { ment pyramid }\end{array}$ & $\begin{array}{l}\text { X7.5 } \\
\text { Having a } \\
\text { role in the } \\
\text { process by } \\
\text { appropriate } \\
\text { employees }\end{array}$ \\
\hline median & 3,862 & 3,830 & 3,370 & 3,693 & 4,052 \\
\hline OR & 1,406 & 1,186 & 1,154 & 1,017 & 0,993 \\
\hline NOR & 0,703 & 0,593 & 0,577 & 0,508 & 0,496 \\
\hline modus & 4 & 4 & 3 & 4 & 4 \\
\hline
\end{tabular}

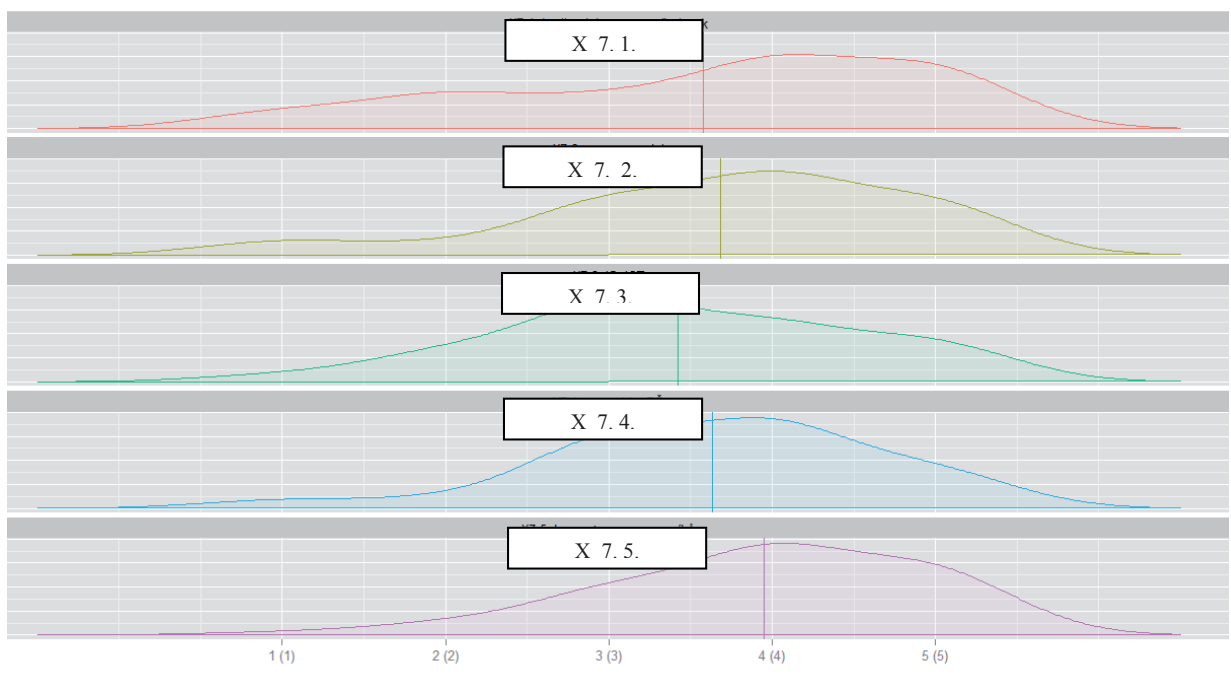

- the impact of company's size according to the number of employees has not been confirmed;

- the influence of the company's size according to turnover can be interpreted by confirmation of the alternative hypothesis H1, i.e.:

„The size of the company according to turnover is significantly linked with the fact that the quality is understood and used primarily as being required by quality standards."

Based on the chi-square test, it can be stated that variables are in dependent relationship at the significance level of $5 \%$. Therefore, the strength of interdependence can be confirmed by $\mathrm{p}$ value $=0,0035$. Given the GKgamma value of $-0,176$ with confidence intervals $(-0,356 ; 0,005)$, the dependency is interpreted as weak. The influence of the industry on the level of understand- 
ing and usage of competences is also very weak, see GKgamma value of - 0,083 with confidence intervals $(-0,356 ; 0,005)$. Its dependence based on the value going over zero is considered as very weak.

The principles of process management require both understanding as well as quality management to come out of the process model. The influences assessed on the basis of size can be evaluated by confirming the alternative hypothesis $\mathrm{H} 1$ :

„The size of the company according to the number of employees (and turnover) has a significant correlation with the fact that quality is understood and considered mainly as a requirement coming out of the process model."

\subsection{Evaluation of Process Segmentation Typology}

The issue of definition and segmentation of processes was comprehensively analysed in detail in the previous sections. The analysis showed that managers have more options of which particular process segmentation to choose. This area of questioning was incorporated into our research since it shows:

- How do managers proceed with process segmentation?

- Which problems are the most frequent?

- How many groups of processes do companies usually have?

- What type of processes are these and what specific attributes do they have?

- Is performance in these processes monitored?

In the questionnaire, respondents were asked to identify the type of process segmentation they use. Fig. 3 shows that the highest number of companies, approximately $60 \%$, use the separation of process groups into managerial (top), main (key) and supportive. This is also clearly supported by ISO 9001 standards. This requirement of segmentation regulation can be further found in practical form in the very first table in this collective monograph. Just a little over one fifth of the respondents $(21,3 \%)$ use Porter's value chain model (primary and supportive processes). Approximately one tenth of respondents $(11,35 \%)$ use value chain approach based on Balanced Scorecard principles (innovative, operational and after-sales processes). 6,38\% of respondents use Earl division, not so often occurring. Even in terms of practicality and ease of use, the most used method of process segmentation (managerial, main and supportive) comes directly from the requirements of ISO 9001. 


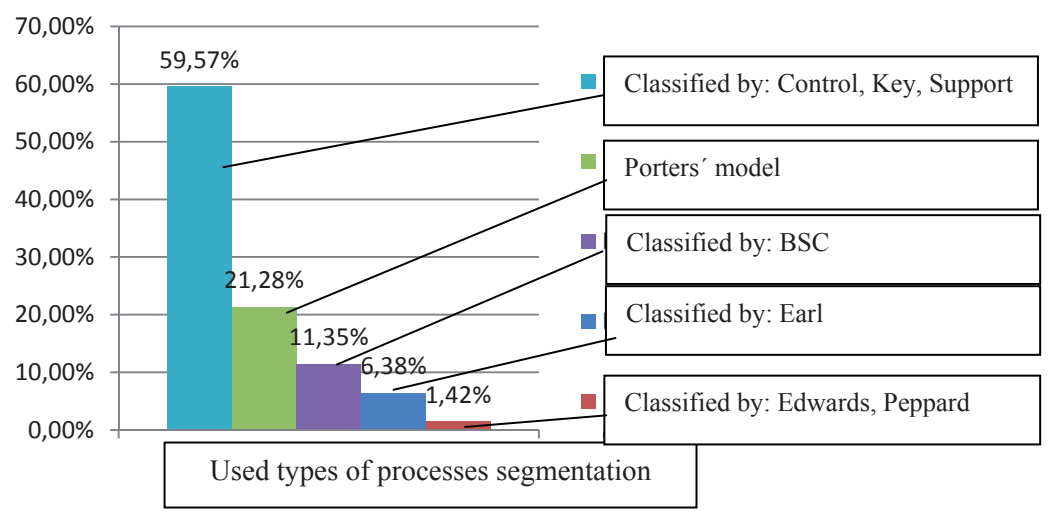

Fig. 3 - Usage of different ways of process segmentation in companies (in 2013). Source: own analysis.

\section{CONLUSIONS}

To sum up the main aspects and reasons for implementing Business Process Management in Czech companies, I can state that that the quality is considered rather as the requirement of quality standards. This means that the trend of more formal description of the current situation in the company is prevailing along with the new concepts. Processes understood and men aged according to this trend bring larger benefits to managers neither in the present nor in the future.

Based on the values listed in Tab. 3 and depending on the extent of how these principles are used, the following principles emerge:

" quality standards that come directly from the process model;

" strategic management which should be seen as the peak of a process management "pyramid".

In case of evaluation of process segmentation typology, I can state that the positive aspects of clear process segmentation reside mainly in improving of their performance. However, in practice, this process classification may cause the situation when some previously highly appreciated specialists will play the role of those who are not in the spotlight anymore.

The influence of size of the company can be seen in Tab. 6. Based on this, it is possible to confirm the alternative hypothesis H1, i.e.: „The size of the company according to the number of employees (and turnover) has a significant association with the type of process segmentation used in the company (on the highest level of groups of processes)." 
Tab. 6 - Usage of different ways of process segmentation in companies (in 2013) statistical evaluation. Source: own analysis.

\begin{tabular}{|l|l|l|l|}
\hline X-squared & $\begin{array}{l}\text { p- value for the size according to: the } \\
\text { number of employees }\end{array}$ & GKgamma & Confidence int. \\
\hline 30,5486 & 0,00600 & 0,172 & $(-0,036 ; 0,38)$ \\
\hline X-squared & $\begin{array}{l}\text { p- value for the size according to: } \\
\text { turnover }\end{array}$ & GKgamma & Confidence int. \\
\hline 44,8127 & 0,00750 & 0,187 & $(0,009 ; 0,365)$ \\
\hline X-squared & $\begin{array}{l}\text { p- value for the size according to: } \\
\text { industry }\end{array}$ & GKgamma & Confidence int. \\
\hline 27,2726 & 0,12040 & N/A & N/A \\
\hline
\end{tabular}

Based on the results from the chi-square test, it can be concluded that variables are in dependant relationship. At the significance level of 5\%, I may confirm the strength of interdependence by $\mathrm{p}$-value $=0,006$. GKgamma value 0,172 with confidence intervals $(-0,036 ; 0,38)$ described a very weak dependence. Moreover, $\mathrm{p}$-value $=0,0075$ represents the value for the size of the company according to turnover. GKgamma value 0,187 again represents a weak dependence. The influence of the industry on the level of process management usage has not been proven (see Tab. 6).

With regard to small businesses (according to the number of employees), Porter's value chain model is the most commonly used classification. This classification includes innovative, operating and after-sales processes along with the managing, key and supportive processes. Even in medium-sized and large companies (according to the number of employees) their managers divide processes into these three groups (managing, key and supportive).

Moreover, medium-sized companies use also value chain approach based on Balanced Scorecard (innovative, operating and after-sales processes).

\section{References}

1. Basl, J., \& Sasiadek, M. (2014). Aplications of the lean principles - comparision study in selected czech and polish companies. In Gerhard, P. D., \& Vaclav, C. (Ed.), 22nd Interdisciplinary Information Management Talks (IDIMT). Czech Republic

2. Cambal, M., Woolliscroft, P., Relich, M., Caganova, D., Sujanova, J., \& Makrajova, J. (2013). The Implications of Tacit Knowledge Utilisation within Project Management Risk. Assessment. In. Green, A. (Ed.), Conference: 10th International Conference on Intellectual Capital, Knowledge Management and Organisational Learning (pp. 645-652). Washington, DC (USA): George Washington University.

3. Croasmun, J. T., \& Ostrom, L. (2011). Using Likert-Type Scales in the Social Sciences. Journal of Adult Education, 40(1), 19-22.

4. Debevoise, T. (2007). Business process management with a business rules approach: implementing the service oriented architecture. Charleston: Booksurge Llc. 
5. Dumas, M., Van Der Aalst, W. M.P., \& Ter Hofstede, A.H.M. (2005). Process-aware information systems: bridging people and software through process technology. Hoboken: John Wiley \& Sons. http://dx.doi.org/10.1002/0471741442

6. Gelogo, Y. E. (2014). Mobile Integrated Enterprise Resource Planning System Architecture. International Journal of Control, 7(3), 379-388. doi: 10.14257/ijca.2014.7.3.36

7. Hammer, M. (2003). The agenda: What every business must do to dominate the decade. New York: Three Rivers Press.

8. Hammer, M., \& Champy, J. (2003). Reengineering the corporation: A manifesto for business revolution. New York: Harper Business Essentials.

9. Hammer, M., \& Stanton, S. (1995). The reengineering revolution: A bandbook. New York: HarperBusiness.

10. Harmon, P. (2014). Business process change: A business process management guide for managers and process professionals (Vol 3.). Amsterdam: Elsevier/Morgan Kaufmann.

11. Jeston, J., \& Nelis, J. (2014). Business process management: Practical guidelines to successful implementations (Vol 3.). New York: Routledge.

12. Lehmann, C. (2012). Strategy and business process management: Techniques for improving execution, adaptability, and consistency. Boca Raton, FL: CRC Press.

13. Nesheim, T. (2011). Balancing process ownership and line management in a matrix-like organization. Knowledge and process management: the journal of corporate transformation, 18(2), 109119. doi: $10.1002 / \mathrm{kpm} .377$

14. Panagacos, T. (2012). The Ultimate Guide to Business Process Managment: Everything You Need to Know and how to Apply it to Your Organization. Amazon.

15. Robson, M., \& Ullah, P. (1996). A practical guide to business process re-engineering. Gower Publishing, Ltd.

16. Rummler, G. A., \& Brache, A. P. (1995). Improving Performance: How To Manage the White Space on the Organization Chart. The Jossey-Bass Management Series. Jossey-Bass, Inc., 350 Sansome Street, San Francisco, CA 94104.

17. Šatanová, A., Hekelová, E., Zavadský, J., Kučerová, M., \& Klementová, J. (2014). Trendy v manažérstve kvality. Zvolen: Technická univerzita vo Zvolene.

18. Segatto, M., Inês Dallavalle de Pádua, S., \& Pinheiro Martinelli, D. (2013). Business process management: a systemic approach? Business Process Management Journal, 19(4), 698-714. doi:10.1108/bpmj-jun-2012-0064

19. Smith, H., \& Fingar, P. (2007). Business process management: The third wave (4th Anniversary ed). Tampa, Fla.: Meghan-Kiffer Press.

20. Son, M. J., \& Kim T. W. (2014). Implementation of an executable business process management model for the ship hull production design process. Journal of Marine Science, 19(2), 170-184. doi: 10.1007/s00773-013-0238-x

21. Stankevičus, K., \& Vasilencas, O. (2014). Research on rules-based business process modelling and simulation. Science: Future of Lithuania, 6(2), 147-150. doi: 10.3846/mla.2014.19 
22. Tuček, D., \& Mikeska, M. (2015) Business Process Management - New Result of Quantitative Research in Czech Republic. In Pavelkova, D. (Ed.) 7th International Scientific Conference Finance, and Performance of Firms in Science, Education and Practice, 2015 (pp. 1565-1582). Zlin: Tomas Bata University in Zlin

23. Tuček, D., Tučková, Z., \& Zámečník, R. (2009). Business Process Management with Software Support. In Knowledge Management and Innovation in Advancing Economies Analyses \& Solutions. 2009 (pp. 1060-1072). Marrakech (Marocco): International Business Information Management Association (IBIMA).

24. Van Der Aalst, W. M. P. (2000). ter Hofstede, AHM, Kiepuszewskei, B., Barros, AP, Workflow Patterns. BETA Working Paper Series, WP 47, Eindhoven University of Technology, Eindhoven.

25. Van Rensburg, A. (2014). Supporting business process design through a business fractal approach. South African Journal of Industrial Engineering, 25(1), 50-61. doi:10.1093/jleo/ewp023

\section{Contact information}

doc. Ing. David Tuček, Ph.D.

Tomas Bata University in Zlin, Faculty of Management and Economics

Mostni 5139, 76001 Zlin, Czech Republic

Email: tucek@fame.utb.cz. 